\title{
Urban social movements in South Africa today: Its meaning for theological education and the church
}

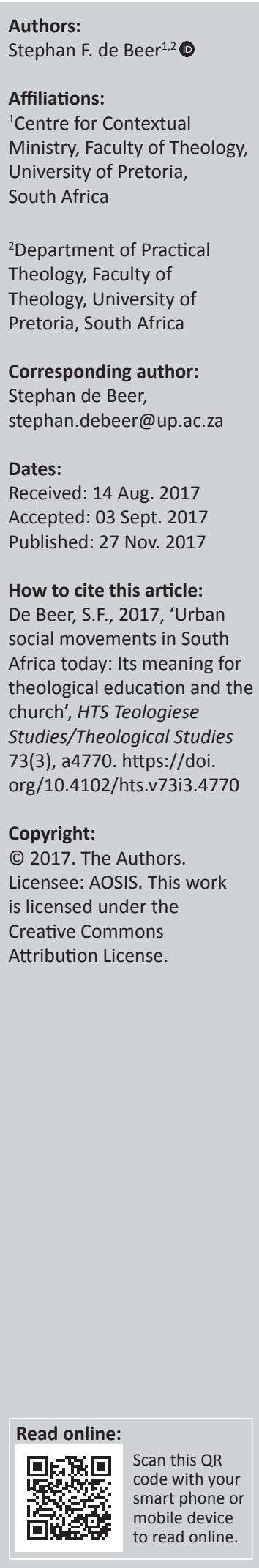

In the past decade, significant social movements emerged in South Africa, in response to specific urban challenges of injustice or exclusion. This article will interrogate the meaning of such urban social movements for theological education and the church. Departing from a firm conviction that such movements are irruptions of the poor, in the way described by Gustavo Gutierrez and others, and that movements of liberation residing with, or in a commitment to, the poor, should be the locus of our theological reflection, this article suggests that there is much to be gained from the praxis of urban social movements, in disrupting, informing and shaping the praxis of both theological education and the church. I will give special consideration to Ndifuna Ukwazi and the Reclaim the City campaign in Cape Town, the Social Justice Coalition in Cape Town, and Abahlali baseMjondolo based in Durban, considering these as some of the most important and exciting examples of liberatory praxes in South Africa today. I argue that theological education and educators, and a church committed to the Jesus who came 'to liberate the oppressed', ignore these irruptions of the Spirit at our own peril.

\section{Urban social movements: Irruptions of the Spirit?}

Theologically I depart from an assertion that the God who works in history can choose to do what is necessary to heal urban fractures, to mend broken hearts, to restore broken cities and to set free the urban poor.

If the church fails to respond in appropriate and bold ways to the challenges South African cities and particularly the urban poor face, and if theological education deliberately chooses to locate itself in disembodied ways as immaterial, intellectual or 'scientific' exercise, largely detached from the struggles of the urban masses who are poor and condemned to urban fringes and who happens to form the majority of the church's urban membership, then God has no obligation to continuously try to change the course of history, or to liberate the urban poor, through the church.

In this article I consider urban social movements as possible irruptions of the Spirit: movements organised around the longing of excluded people, or nonpersons, to reclaim their humanity, their place in the city and indeed their right to participate in making the city. I trace three such movements - Ndifuna Ukwazi (NU) and Reclaim the City in Cape Town, the Social Justice Coalition (SJC) in Cape Town and Abahlali baseMjondolo based in Durban - considering their possible meaning for theological education and the church through the lenses of Gustavo Gutierrez, David Harvey and Marie Huchzermeyer.

\section{Listening to the Spirit from (un)expected places}

Before, I might have said that the church and theological education have to listen to the Spirit through hearing the groaning from unexpected places: the groanings of the poor, but also of the water, the forests and the whole earth (cf. interview with Leonardo Boff; TeleSUR Reports 2014). In history it was often, if not always, from the underside that truth was spoken to power, jesters emerged and dominant discourses were dismantled. Only those with nothing to lose are willing to speak the truth. Why those are thought of as unexpected places is because those places are poor, disenfranchised, delegitimised and seen as unable to think for themselves, to be clear and incisive or to hold wisdom that could contribute to the greater good.

The shocking remarks of the presiding Judge of the High Court, Judge Leslie Weinkove, in the eviction case of the Bromwell Street residents, demonstrate this (cf. Evans 2017; Mortlock 2017a). In reference to Charnell Commando, spokesperson of the evicted residents, he said:

Note: The collection entitled 'Spirit rising: tracing movements of justice', forms part of the 'Faith in the City' research project, hosted by the Centre for Contextual Ministry in the Faculty of Theology, University of Pretoria. Some of the articles were papers presented at the Biennial Consultation on Urban Ministry, hosted by the Institute for Urban Ministry, in collaboration with other organizations, from 17-20 August 2016. The theme of this Consultation was '\#We must rise: healers - dreamers - jesters'. 
What's her name? Charnell? She is a kitchen assistant in Observatory and now she's an expert. She doesn't know what the budget of the City Council is; she doesn't know what money they get. She doesn't know this stuff. She is a kitchen assistant. (Evans 2017)

In this article I would argue, instead, that we need to listen to the Spirit whispering, crying, shouting, from to-be-expected places: those places in which people are systematically deprived of access to the city and its resources, condemned to a second-rate occupation of the city and berated or criminalised for being poor. It seems inevitable that the moment would arrive in which frustration and anger would reach a point of no return: either boiling over in powerless acts of violence or channelled into creative acts of resistance. (Even if turning violent, to condemn such responses outright without an equally strong condemnation of the structural violence or exclusion that becomes the fertile soil for producing violent eruptions, would be to simply deny the on-going, sometimes even generational violence or inhumanity the urban poor have been dealt all along).

I locate my reflections in three urban social movements, describing their mission, providing examples of their actions, reflecting on postures characteristic of all three and wondering how theological education and the church could learn from them.

\section{Ndifuna Ukwazi and Reclaim the City}

NU is the first locus of reflection. Not created as a social movement to start with, it was established as 'an activist organisation and law centre that promotes the realisation of Constitutional Rights and Social Justice - through legal, research and organising support to working class people, communities and social movements' (Ndifuna Ukwazi 2017). $\mathrm{NU}$ is supporting a range of progressive social movements not only mainly focusing on issues related to urban land justice but also attending to issues related to service delivery, access to information, monitoring of procurement at local government level, budget education and advocacy and activist education (cf. Ndifuna Ukwazi 2017).

Their most recent campaign, taking centre stage in community activism in Cape Town and contributing to shift public sentiment and inform public policy, is titled Reclaim the City. Spearheaded by NU it has managed to galvanise broader based support and something of a movement is emerging around issues of right(ful) access to the city, but in particular to strategic locations in the city, deliberately undermining dominating market discourses that always seek to restrict poorer communities to the urban fringes.

Here is how the vision and intentions of Reclaim the City are articulated on the Ndifuna Ukwazi (2017) website (see Box 1).

In order to ensure the realisation of this vision, Reclaim the City was launched on 13 February 2016 as a campaign, led by a chapter of domestic workers and low-income workers in
BOX 1: Reclaim the City.

Cape Town is one of the most segregated cities in the world.

Unregulated rents and property prices are forcing poor and working class people out and there is not enough well located affordable housing. The City and Province say they have no land but are selling or leasing land that could be used for mixed income affordable housing - this has to stop. NU is supporting people for mixed income affordable housing - this has to stop. NU is supporting people who live and work in the CBD to Reclaim The City and ensure Land for People,
Not for Profit.

Sea Point, advocating 'desegregation and affordable housing in the inner city' (Ndifuna Ukwazi 2017). This campaign has become something of a movement, also supported now by 'poor tenants in Woodstock and Salt River, young professionals, high school pupils, students and workers from across Cape Town' (Ndifuna Ukwazi2017). In the last months faith-based activists have increasingly been organising their own constituencies around a housing agenda, largely inspired by this campaign. They insist that the state is obliged to lead the process of reversing spatial apartheid in Cape Town (cf. Ndifuna Ukwazi 2017).

Two specific sites became initial locations of resistance and advocacy: Bromwell Street in Woodstock and the Tafelberg School in Sea Point.

Residents of Bromwell Street in Woodstock - some whose families have lived for four generations in their houses were evicted when new landlords purchased their properties (cf. Baadjies 2016). There was no alternative anywhere in central Cape Town or in the vicinity of Woodstock that was accessible and affordable to Bromwell Street residents, although this was where their children went to school, where their social networks and relationships were and where those of them who had work were in the vicinity of their jobs.

The City of Cape Town could only offer an alternative $30 \mathrm{~km}$ away in Blikkiesdorp and Wolwe River. These are transit sites offered by the city to evictees, providing informal housing, designed to accommodate people for 3-6 months only until appropriate alternatives were found and yet many people have now lived there for more than 5 years already (cf. Gerardy 2010). The result is that Bromwell Street residents resisted relocation to these far-off sites, arguing for the necessity to have alternatives available in central locations of the city and not far from where they lived in Woodstock.

Although this seems like an isolated case, the Bromwell Street residents actually represent thousands of people who are displaced on a regular basis in cities and towns around South Africa, when market forces push them out or lack of affordable housing in central locations prevent them from accessing decent housing in the first place. It is symptomatic of the apartheid city structure, which has not been reversed and over the past two decades became one of the major reasons of urban homelessness. That this is not in the public eye is because mostly people in such situations are extremely vulnerable, lacking the financial resources to fight their evictions or to access proper legal support. All their energies go into avoiding their already precarious housing situations rendering them homeless. In the case of Bromwell Street, it was NU and the Reclaim the City campaign that helped 
expose the plight not only of the Bromwell Street residents but also of all people in such situations, seeking to create public awareness through exposing the fault lines in the city, when capital and political power are left to their own devises, overseeing the displacement and marginalisation of the poor.

Faith communities are often aware of these realities, both because of having a local presence in communities and because affected people might belong to faith communities. And yet, the general silence of faith communities makes them complicit in the exclusion of the poor from the city. They might be aware but not in a way that shapes a new or critical kind of consciousness with them. They mostly lack a theology able to make sense of urban processes and forces that are death-dealing; or to resist exclusionary practices; at best providing tentative, inappropriate even, pastoral support or perhaps a few nights of temporary accommodation. Seldom does the church's pastoral or diaconal functions enable it to be in deep solidarity with vulnerable people such as the Bromwell Street residents, either prophetically challenging the power of capital to do as it pleases or the state's unwillingness or inability to either intervene or provide decent and appropriate alternatives.

The second site that highlighted this contest for space in the city was the Tafelberg School in Sea Point (cf. De Villiers 2017; Furlong 2017; Mortlock 2017b). A property owned by the Western Cape Provincial Government, the site was to be sold to private owners to accommodate a new private school. Again, the Reclaim the City campaign, with the support of $\mathrm{NU}$, used this opportunity to build a strong agenda for affordable housing in good locations in the City of Cape Town. Their argument was simple, stating that public land should not be sold to the highest bidder, as it presented one of the few opportunities to reverse spatial apartheid, and that it should rather be used for social housing in central locations of the city.

They ran a very effective campaign in Sea Point and were even able to gain the public support of large parts of the local community, also the sizeable Jewish community, many of which are employers of the domestic workers running the Sea Point chapter of Reclaim the City. In the centre of Cape Town they had a very public display on Long Street, the city's hub of party-goers and tourists. In spite of growing public support for social housing in Sea Point, the High Court ruled in favour of Provincial Government, allowing them to sell this site to the private school (cf. Mortlock 2017b). One of the reasons Provincial Government provided the site was that Sea Point did not fall in a restructuring zone, and therefore social housing subsidies could not be made available in this area (cf. De Villiers 2017). Of course, this further exposed their lack of political will, especially when, within a week of the High Court decision, the City of Cape Town made the potentially far-reaching decision to declare the whole of Cape Town a restructuring zone, paving the way for social housing anywhere in the city, once a proposed project is proven viable (cf. Furlong 2017).
In spite of a growing campaign and increasing public sentiment in favour of Reclaim the City's assertions, the Western Cape courts seem not to share this commitment to spatial transformation of an extremely fragmented city. The courts ruled in favour of private landlords and provincial government, each time failing to provide leadership in terms of advancing access for the urban poor.

The City of Cape Town's response to declare the whole city a restructuring zone is a rather progressive and welcome decision and seemingly also a direct challenge to their provincial counterparts. They also indicated that the old Woodstock Hospital and the Robbie Nurock Community Day Centre were two of six sites in the Woodstock and Salt River earmarked for social housing provision (cf. Hogg 2017). Upon enquiry from housing activists, the City failed however to provide timeframes or guarantees of budgets. This prompted a next action on the part of Reclaim the City, now occupying two sites promised by the City for social housing - the Woodstock Hospital in Woodstock and the Helen Bowden Nurses Home in Green Point - 'in the meantime', almost 'keeping it for the city' to make good on its promises (cf. Pillay \& Sendin 2017). It became a very public declaration advocating access to decent, affordable housing in strategic locations, challenging on-going urban spatial segregation.

\section{Social Justice Coalition}

The Social Justice Coalition (SJC n.d.) is a membershipbased social movement originating in Khayelitsha, but now including membership also from communities such as Crossroads, Gugulethu and Kraaifontein. SJC's 2500 members come from 17 branches and mainly live in informal settlements.

SJC summarises its mission in this way: 'We work to advance the constitutional rights to life, dignity, equality, freedom and safety for all people' (SJC n.d). They run two programmes the Local Government Programme and the Safety and Justice Programme-which focus on a number of thematic categories, all central to the lives of people living in urban informal settlements such as Khayelitsha: sanitation, budget, urban land, policing and social audits. These themes emerged not from a place of excellent service delivery or just budget allocations, but from a growing discontent - indeed, a deep sense of pain - at the ways in which people are excluded from the tables of the city. As a social movement, SJC is refusing to be passive observers but engages local government in a vigorous and sophisticated manner, grounding their campaign in solid research, educating their members in terms of both their constitutional rights and the principles of developmental local government.

Here I will only briefly attend to work they have conducted in the areas of sanitation, budget and safety or policing.

In Khayelitsha, one-third of residents have no access to water and a quarter of residents have no access to flush toilets connected to a sewage system. Hundred thousand people 
have no access to sanitation facilities (cf. SJC n.d.). This prompted SJC to launch their sanitation campaign in 2009. After many years of engagement with the City of Cape Town, with limited effect, SJC finally decided to take the City to court, once again with the support of NU. Departing from an assertion of residents of informal settlements having an equal right to quality education to all other citizens, they advocate for proper long-term infrastructure to be installed instead of the current temporary sanitation solutions given. Through their work, church-based organisations and the broader public are educated on the harsh realities people face in informal settlement communities and also equipped with information that helps see the gross disparities, 23 years into democracy.

Obviously, this is a budgetary issue and SJC has embarked on an extensive process to educate its members on the City's budgeting process, as part of their demand for 'a fair, equal and just budget' (SJC, n.d). In 2016, for example, the City's water and sanitation capital budget was $\mathrm{R} 1.5$ billion but only R15 million was budgeted for informal settlements, R5 million down from 2014, and only 1\% of Cape Town's total capital budget was for water and sanitation, although $21 \%$ of Cape Town's households lived informally. In 2014, only 27 submissions were made by residents in SJC communities, as part of their public participation in the budgetary process. In 2016 and 2017 no less than 3000 submissions came from residents living in Khayelitsha and Nyanga, leading a local politician, Councillor Sonnenberg, to say: 'The SJC is obsessed with budgets' (cf. SJC n.d).

The SJC of course liked that line, now using it on banners during public events and marches, because, indeed, the distribution of budgetary allocation is an issue of justice, quality of life and, sometimes, means the difference between life and death.

Another matter of life and death, very literally so, is safety in informal settlements and the quality of policing. The Khayelitsha Commission of Enquiry into policing, chaired by Kate O'Regan and Vusi Pikoli, was the result of more than a decade of struggle for local communities to access justice in the form of safety, security and proper policing. Led by the SJC, in conjunction with a range of other civil society organisations, this campaign was the result of consolidating many individual experiences of crime and police efficiencies into one consolidated campaign Once approved, the thenMinister of Police opposed the formation of such a Commission in both the High Court and the Constitutional Court; but he failed and the work of the Commission could go ahead.

The Commission made 20 recommendations, relating to 'the powers and duties of the police, the right of communities to hold police accountable and the duty and right of a province to protect its residents from violent crime'. The work of the SJC is to monitor implementation of the recommendations made. However, once again the Minister of Police failed, according to SJC, and therefore they had to go back to court in 2016, this time represented by the Legal Resource Centre. Their court application in this case was to 'change the inequitable and irrational allocation of police resources in poor and working class areas and to ultimately give substance to the Commission's recommendations'. On 23 September 2016, the Court ruled in favour of SJC and the Minister of Police has to see to the implementation of both the Commission of Enquiry's recommendations and now also this court order.

Once again, at the heart of SJC's plea was the unequal distribution of human and financial resources. Nyanga, namely, had the most murders and sexual crimes in Cape Town, yet was the fourth least resourced police precinct in Cape Town. Allocation of human resources clearly ran along racial lines with Cape Town Central, Camps Bay, Wynberg and Sea Point amongst the five best resourced police precincts (cf. SJC, n.d).

Through their work, SJC's members refuse to be victims any longer, but work as active agents for the socio-economic liberation and well-being of their communities, mainly through increased access to that which constitutes dignified living and just distribution of the city's resources.

\section{Abahlali baseMjondolo}

Abahlali baseMjondolo is probably the largest social movement of its kind in South Africa, with members now numbering 30 000, coming from 30 informal settlements, predominantly in and around Durban, but also elsewhere in South Africa (cf. Abahlali 2016a). Somewhat different from SJC, Abahlali more clearly define themselves as an organisation or movement of the militant poor, comprising entirely shack dwellers. Their origins date back to 2005 when the Kennedy Road informal settlement blocked the road in protest against the sale of nearby land to an industrialist, even though promised by a local politician for housing people living on Kennedy Road. The movement grew in leaps and bounds from there, becoming a voice for thousands of shack dwellers (cf. Abahlali 2016a).

Their key campaign is for access to land and housing in the city, but in the process, they also fought against forced removals, and for access to water, sanitation, electricity, refuse removal, health care and education. In some communities, they were successful in setting up crèches, food gardens, soccer clubs and art and music competitions.

Although now contested by some who left the movement, Abahlali works hard to practice bottom-up popular democracy. They challenge non-government organisations (NGOs), academics and donors who pretend to speak for the poor, insisting on articulating their struggles themselves, on their own terms and to propose solutions from within. It is in this context that they speak of the University of Abahlali (cf. Abahlali 2016b), refusing 'to be the objects of research and rather suggests as the vocation of engaged scholars 'to find new ways of listening to those who continue to be 
silenced and dehumanised' (Gibson 2011:40; De Beer 2014; Pithouse 2006).

Abahlali's represents what Fanon (1968:146) speaks of as 'shifting the geography of reason', inviting those on the outside - and in the context of this article it would include the church and theological educators or institutions of theological education - to consider sites of struggle and the voices of the poor as 'the source of a new way of knowing' (Gibson 2011:8). Theirs is a call for new and reciprocal spaces in which to explore 'mutually liberating knowledge' (cf. Gibson 2011:179; in De Beer 2014).

Although their struggles are very concrete, and often about the life or death situations of their members, they have developed a very clear and assertive theoretical underpinning to articulate the ultimate goals of their struggle:

[t]hey insist that their protests are not about service delivery, which would just keep them dependent on the good will and handouts of government officials and politicians; their protests are about a new way of doing politics, a democratisation from below, an assertion of their participation in determining their own futures, a cry for a new way of being human together. (De Beer 2014)

\section{A domesticated Jesus, theological education and the church}

The struggles, strategies and tactics embodied by the movements described above somehow seem a far cry from the decency and orderliness of the average church-goer, church gathering or theological school. Even if many members of churches are poor themselves, residents of informal settlements or other precarious housing situations, their local churches most often would seek to provide remedies for the soul, perhaps, but be rather powerless in the face of the socio-economic and political odds stacked against them and their members, as if such challenges of life fall outside the scope of God's concern.

It is perhaps such a powerless faith, the almost wimp-ish retreat in the face of gigantic forces of power and greed that aggrieve me and that is aggrieving many who found a voice in the face of death-dealing injustices. In the face of the struggles of the urban poor and their fighting for survival, the Jesus of most of our churches and theological schools is decent and orderly, co-opted and domesticated into the image of those who run our institutions.

This Jesus whinges at the idea of turning tables upside down; for this Jesus, the cross is not a protest against every form of death, as Moltmann (1983:33) describes it; nor the outcome of a politically orchestrated collusion between imperial and religious leaders to silence him, but the fate of a powerless, make-believe king; tamed from engaging messiness or chaos; condemned to impotency or irrelevance.

Do I advocate indecent churches or disorderly theological schools? I suppose what I do agitate for is for churches and theological schools to be disrupted, liberated and transformed by the voices of the poor and those occupying the underside of the city. I found in my many years of engagement with inner city and other urban realities that theological education - both in content and pedagogy - is largely ill-equipped to prepare future urban practitionertheologians to be able to facilitate deep, transformational change.

I am challenged by Abahlali's (2016b) assertion that their intellectual project is based on a decision that 'when order means the silence of the poor then it is good to be out of order'. If the voices of the poor and excluded are silenced in corridors of power, in cities and universities, in churches and theological schools, then we have to revert to the indecency of the Jesus who drove the decent ones from the temple to make space for everyone.

We do not have to scratch too far to encounter the suburban consciousness of dominant theological educational models in South Africa today. There might be the odd exception, but even those who have rich contextual or liberation theological roots have often 'graduated' away from the radicality of such theologies; or, if their intellectual constructs still pay lip service to such theologies, they often fail to demonstrate deeply embedded actions of solidarity, instead becoming new orthodoxies, seldom practiced in the way such theologies were birthed.

Without exploring it in greater detail here, but something to be explored further elsewhere, is the absence of spirituality from doing theology, which will then inevitably result in the absence of a life-affirming praxis, as our way of doing theology. Without a liberationist spirituality, embedded in a life-affirming - and death-confronting praxis, theological education and the church might easily be co-opted into a false consciousness by violent constructs of bad power or pervasive whiteness (cf. Kritzinger 2008; Perkinson 2004; Van Wyngaard 2015, 2016).

A spirituality of liberation or conscientisation then needs to be found in places outside the dominant ecclesial or theological structures, which bear very few traces of such spiritualities. This article is meant to lament that fact, whilst seeking to learn from urban social movements, to help transform the church and its theological education.

\section{Reflecting theologically on 'irruptions from below': What do we have to learn?}

In this section I now consider four postures that emerge for me from the three movements I described, reflecting on them theologically: irruptions from below, friendship with the poor, resistance of dominant city-making practices and informality as insurgency. 


\section{Irruptions from below}

Gutierrez (1988:xx) speaks of liberation as the irruption of the poor'; which according to him is 'a far-reaching historical process' bearing an 'imprint of the new presence of those who in fact used to be "absent" from our society and from the church'. He explains such absence as people or communities being viewed as 'of little or no importance, and without the opportunity to express themselves to their sufferings, their comraderies, their plans, their hopes' (Gutierrez 1988:xx).

To Gutierrez (1988:xxi) this new presence, exemplified by the movements of those who are poor, oppressed or marginalised, is what 'liberation theology is closely bound up with'. The historical processes of the poor for justice are simultaneously a process of claiming and asserting their own agency, shaping their own destiny, and beginning a resolute process that is changing the condition of the poor and oppressed of this world' (Gutierrez 1988:xxi).

In the organising of the movements I have introduced earlier, such an assertive claiming of agency is very clear: a refusal to remain compliant in a society which denies their humanity, aspirations and right to the city.

The challenge faced by theological education and the church is to refine our tools of analysis, as we try 'to understand better where and how the Lord is challenging us as we face the life and death of our brothers and sisters' (Gutierrez 1988:xxv). If we understand such movements as irruptions of the poor to change the course of history, to shape the human story and local spaces, and therefore as movements expressing the desire of the Spirit, then it is a challenge of locating ourselves where those participating in such movements can become our dialogical partners, our interlocutors and interpreters of situations we do not always know or understand existentially. They might be people of religious faith or not, but they are definitely people of great faith in the possibility of radical alternatives, sometimes to the shame of the institutional church.

We have to make the conscious choice, according to Gutierrez (1988:xxix), to make '[t]hose who are "nonpersons," deprived of their full rights to be human and free, our dialogical partners'. In urban settings, such dialogical partners will be those denied a right to the city, a right to access urban resources and a right to participate in urban decision-making, as equal human beings.

\section{Friendship with the poor}

For Gutierrez this is not merely a tool for analysis or a theological gimmick used to access worlds we do not have experience of. For him, who himself lived in a slum in Lima most of his life, it goes much deeper though, described in a language of friendship: 'If there is no friendship with them and no sharing of the life of the poor, then there is no authentic commitment to liberation, because love exists only among equals' (Gutierrez 1988:xxxi).
How many theological schools in South Africa can claim such closeness to the lives of the poor, and, in the absence of that, do we hear the words of Gutierrez, questioning our authentic commitment to liberation? Wherever the poor are not central in shaping our theological discourse, or friends of us who teach at theological institutions, therefore able to challenge our praxes even just through their presence in our lives, we run the risk of speaking of love without practising it, because, says Gutierrez (1988), 'love exists only among equals'.

\section{This is his challenge:}

You cannot really be with the poor unless you are struggling against poverty. Because of this solidarity - which must manifest itself in specific actions, a style of life, a break with one's social class - one can also help the poor and exploited to become aware of their exploitation and seek liberation from it. (p. 172)

Our commitment to the poor will show itself in deep friendship, lifestyles of deep solidarity and deep struggles to overcome poverty.

Schools of theology and dominant churches are geared to the contrary: to prepare people to graduate - up and out, away from poverty and not primarily for a life committed to liberation of the poor. That is why movements such as Abahlali are very discerning as to who they are prepared to journey with - who, namely, can be their friends in a way that exemplifies the equality of love.

\section{Resisting dominant city-making practices}

Huchzermeyer (2011:11) speaks of ' $[t]$ he emergence of a network contesting "slum" eradication and promising a right to the city'. In South African cities, there are different responses to the eradication of informal settlements through displacement, or the eviction of the urban poor, whether legal or illegal evictions, to make space for the gentrification of neighbourhoods. Some responses are haphazard, or reactive, at best, whilst other responses are well organised, forming part of more deliberate and strategic tactics and actions of resistance.

Urban social movements such as NU, SJC and Abahlali engage, amongst other things, the concept of urban competitiveness, characterised by corporatisation and commodification, also of public spaces and utilities, and the ability to mediate access to services and resources for the city's most vulnerable populations (cf. Huchzermeyer 2011:49).

Cities often divert essential resources away from the environment, social welfare and other social concerns (Douglas 2002:57), investing instead in 'mega-projects' such as 'high-speed trains and huge convention centres and sports complexes', seeking to boost their international status. This happens at the expense and through the exclusion of the poor. Public investment and public expenditure on urban shelter and services are completely 
insufficient in relation to the actual available urban resource base (cf. Huchzermeyer 2011:59).

With reference to Murray (2008:14) and Gibson (2011:20), Huchzermeyer (2011:59) writes: 'eradication, eviction, relocation, and resettlement go hand in hand with modern world-class city aspirations'. It is precisely such city-making practices that my interlocutors in this article seek to resist.

\section{Informality as insurgency}

Murray (2008:33) speaks of informal settlements as 'incubators for inventive survival strategies where inhabitants have begun to reclaim available space for multiple uses, develop their own specific forms of collaboration and cooperation and reterritorialize their connections both inside and outside the city'. The specific practices, or 'living politics', practised by Abahlali is a poignant example.

Holston and Caldeira (2008:18) detect in informal settlements 'spaces of creativity and agency', as well as in the words of Huchzermeyer (2011:88), 'an insurgent creativity', to create 'something new that cannot readily be assimilated into established conceptual frameworks' (Holston \& Caldeira 2008:19). The insurgency of the poor, as expressed amongst other things in urban social movements, or in informal settlements, are described as 'a counter-politics' (Holston 2009:15) or 'the material expression of poor citizens' insurgency' (Miraftab 2009:35), which 'destabilizes the dominant regime of citizenship, renders it vulnerable, and defamiliarizes the coherence' (Holston 2009:15).

Insurgency is not always expressed in an organised fashion through social movements but often rather spontaneously occurs as a lived response of disempowered people, to outwit the forces aligned to keep them down. Bayat (1997:55) speaks of 'the vast arrays of often uninstitutionalised and hybrid social activities' and (Bayat 1997:57) 'a silent, patient, protracted and pervasive advancement of ordinary people on the propertied and powerful in order to survive hardships and better their lives'. These could be expressions of a politics of protest but also of redress that is aimed at the redistribution of sources of livelihood, and the assertion of cultural and political autonomy (cf. Bayat 2000:548).

\section{Incongruence between our languages or visions and our actions or embodiments}

There is a deep difference between a commitment to the poor, deep solidarity with the poor and active participation in processes against those forces continuing to oppress and exclude people into poverty, on the one hand, and verbal or dogmatic articulations about the poor, on the other (cf. Gutierrez 1988:173).

We might have a language of liberation or commitment to the poor, without actually being committed to the poor or without actual practices embodying such languages or commitments (cf. Gutierrez 1988:174). Gutierrez (1988) says:

we will have an authentic theology of liberation only when the oppressed themselves can freely raise their voice and express themselves directly and creatively in society and in the heart of the people of God, when they themselves 'account for the hope' which they bear, when they are the protagonists of their own liberation. (p. 174)

In liberation theology, the content of Biblical revelation and the longings or cries of the poor come together in the content of Christ's liberation (cf. Gutierrez 1988:xxxviii) - in fact, the combination of these two elements becomes 'the essential content of evangelization'. Urban evangelisation will seek to flesh out the good news of Christ in terms of and in relation to the cries and exclusions of 'nonpersons':

... the poor challenge the church at all times, summoning it to conversion; and many of the poor incarnate evangelical values of solidarity, service, simplicity, and openness to accepting the gift of God. (Gutierrez 1988:xlii)

In theological education (and in churches) such distances between languages and actions, visions and embodiments, abstractions and concreteness, are acute. Gutierrez (1988:xlii) refers to James $1: 8$ and $4: 8$ challenging such doublemindedness: speaking one thing and doing another. $\mathrm{He}$ (1988:xliii) says: 'What brought Jesus to his death, and is bringing his present-day followers to their death, is precisely the coherence of message and commitment'. It is the coherence of language and actions that become dangerous; it is such coherence in theological schools and education that holds the potential to make change.

What prevents us perhaps from such coherence is the inconvenience; the sacrifice that is bid by commitment; the spatial, social, economic and experiential distance from the poor; the ways in which dominant theologies and those producing these are mostly dismembered from the poor, by design and by choice.

\section{Epistemological distances: The difference between hope and hopelessness}

There is an epistemological distance between those participating deeply in urban and other social movements, with nothing to lose; almost recklessly committed to a radically new reality, away from the oppressive and exclusive cards they have been dealt, and those inhabiting different, and by definition more comfortable, 'decent' and safer residential, theological or ecclesial spaces. This intensity of urban social movements is not understood by those not sharing their lived realities. Gutierrez (1988:122) ascribes such apathy or distance, or the lack of intense political (or theological or spiritual) experience or solidarity at least, to an attachment 'not to the past, but rather to an affluent present which they are prepared to uphold and defend under any circumstances'. 
In liberation theologies much emphasis is placed on discerning the signs of the times. Gutierrez (1988:7) asserts, though, that this is no merely an intellectual exercise but combines pastoral activity, service and commitment. Discerning the signs of the times furthermore requires hearing, distinguishing and interpreting the many voices around us, also competing or contesting voices, and then judging or discerning these voices 'in the light of the divine Word' (Gutierrez 1988:7).

There is a strong focus on going beyond the boundaries of the church as the primary locus for theological reflection. In order for the church to participate and mediate liberation in relation to some of the greatest challenges of the world, theology cannot only use as sources of theologising that which is traditionally known or valued as revelation or tradition, without also engaging questions, challenges and voices coming from contemporary challenges in society, and those responding to such challenges, such as the wisdoms embodied by social movements (cf. Gutierrez 1988:9-10).

A spirituality and praxis of liberation, although fiercely critical at its core, is at the same time fiercely hopeful, unlike the cynicism and hopelessness often ironically found in institutions of privilege serving as custodians of the status quo. It is because of its insistence on a different future. Gutierrez (1988:11) says: 'The present in the praxis of liberation, in its deepest dimension, is pregnant with the future'. It emanates from, what Ernest Bloch calls, 'an active hope which subverts the existing order' (Gutierrez 1988:123).

And yet, it is precisely the pregnancy of such a hope, the possibility of subverting and transforming the existing order, that those with much to lose defend so much. At the point of our contesting epistemologies, a tension - or incongruence opens up between what is proclaimed and what is experienced: open gates, open universities and open cities, as projected image on the one hand and the increasing inequalities and marginalisation of the poor and those protesting death-dealing practices that continue to hurt and exclude the poor, on the other. Such a hope mobilises 'human action in history' (Guttierez 1988:123), in the direction of a radically different future, through transforming the present, which includes to call out the deceptions of our incongruence.

\section{Humanising the city}

Huchzermeyer's (2011:59) own work emphasises informal settlements as 'the uncommodified, human face of South African cities'. The workings of these communities, she asserts, 'play no active part in the socio-economic process that deepens poverty'. She deliberately emphasises a humanising discourse to counter pervasive discourses of informal settlements as a threat to urban life and stability. Without romanticising the harshness of informal settlements, Merrifield (2002:172) speaks of it as 'cities made liveable by people struggling to live'. Huchzermeyer (2011:83) concludes that such struggle to live 'can take many forms, including mobilization, collective negotiation, litigation, protest and a combination of all these, alongside "quietly claiming"'.

In an urbanising world, this directly relates to the kind of city we want. Harvey (2012:4) holds that we cannot ask the question about the kind of city we want, without asking 'what kind of people we want to be, what kinds of social relations we seek, what relations to nature we cherish, what style of life we desire, what aesthetic values we hold'. It is really the question about how we want to be human together in the cities of our world. In South Africa, with its particularly dehumanising history, where the nonperson was institutionalised through the socio-spatial fragmentation of urbanity, the humanising work of rebuilding urban societies remains.

The words of Harvey - 'what kind of people we want to be' - seem to me a profoundly theological question: who are we as image-bearers of God; how do we want to be in relation to the other; and how do we overcome the legacy of entire townships being seen as composed of 'nonpersons'?

S'bu Zikode (2017) from Abahlali baseMjondolo often emphasises this: '... the struggle we are engaged in is not just about the so called 'service delivery' but the full restoration of our human dignity'. It is about humanising the city in a way that fully affirms or restores the humanity of every inhabitant. This was also the conclusion of Elina Hankela (2014), tracing the practices and theology of the Central Methodist Mission and Bishop Paul Verryn, when still hosting hundreds of foreign migrants in their church property: it was a journey of a Johannesburg church, its members and its inhabitants, being, and becoming, human.

\section{A much deeper struggle or revolution for justice: These are only small steps}

The actions of the urban social movements described here above are indeed about a much deeper struggle than just resisting an impending eviction or lobbying against the sale of one parcel of public land to the highest bidder. It is a struggle for humanity, for the kind of humans we want to be together in dense urban spaces, for the ways in which we want to live our lives with hope, for the kind of society in which justice and peace will not be pipe-dreams but articulated through the architecture of our neighbourhoods, the distribution of our resources and the agendas of our theological curricula.

In attending to the work and voices of these social movements, our theologies should indeed be under scrutiny, without any reservations. We should consider Gutierrez' (1988) plea for:

\footnotetext{
... a theology which does not stop with reflecting on the world, but rather tries to be part of the process through which the world is transformed. It is a theology which is open - in the protest against trampled human dignity, in the struggle against the plunder of the vast majority of humankind, in liberating love,
} 
and in the building of a new, just and comradely society - to the glory of the Kingdom of God. (p. 12)

Are our practices of teaching, research and engagement with communities in the sign of such a solidarity that protests human indignities, the plunder of the earth or segregationist urban practices? Or do we peddle timid theologies, speaking in the abstract about the concrete suffering of God in suffering urban people, disembedded from grass-root pain, indeed absent from the places outside the gate where Jesus met his fate?

Freedom for Gutierrez (1988:21) is an on-going process of human liberation, moving from abstraction to a real and embodied 'struggle against all the forces that oppress humankind'. But Gutierrez (1988:21) speaks of it as a struggle fraught with 'pitfalls, detours, and temptations to run away'. It is a struggle made up of millions of smaller and bigger steps in the same direction. Urban social movements, often quite specific in the agenda around which they organise, do not fall outside the realm of this larger process for human and ecological liberation. Because the processes of capital and its accumulation, both in its intensity and effects, are concentrated in cities, urban places have become ideal sites for resistance and the grounding of larger scale resistance movements (cf. Harvey 2012:120).

Because urban social movements focus on access to the city, urban space, urban housing and different forms of urban resources, they were traditionally viewed quite differently from other movements dealing with labour and alienation through processes of production and ownership (cf. Harvey 2012:120). They were even dismissed as mere off-shoots of the more fundamental class struggles residing in labour (cf. Harvey 2012:120). Struggles about rights or citizenship were seen as different from broader class struggles.

Harvey (2012:iii) argues for a broader understanding of the nature and agenda of urban-based social movements. Class struggles are not limited to the workplace. In a South African context, millions are unemployed in our cities and their exclusion even much more acute than experienced by those who are actively working. Spatial and housing organisation is fundamentally class-based in South Africa, and therefore, any spatial conversation cannot but engage a proper analysis and discernment of the working of capital:

Urban social movements therefore always have a class content even when they are primarily articulated in terms of rights, citizenship and the travails of social production. (Harvey 2012:129)

The struggles for access to water, sanitation, education or health care can never be seen as detached from the classbased society. Theorists like Gutierrez and Harvey agree therefore that what is required is much more radical.

Harvey (2012:xviii) speaks of the pervasiveness of dominant practices to uphold an exploitative and oppressive status quo. The ultimate goal should be 'to eradicate those practices through a much broader revolutionary movement' (Harvey 2012:xviii), requiring intersectional alliances across the broadest possible base. For Harvey (2012:xviii) therefore, the agenda of a 'right to the city' approach 'is a way-station on the road to that goal. It can never be an end in itself ...'.

The goal of this struggle - or, of asserting the right of everyone to belong, participate, share and create the city fully - is indeed not just better living conditions or radical structural changes. Gutierrez (1988:21) describes the bigger goal as such: 'It is much more: the continuous creation, never ending, of a new way to be human'. It is, for Gutierrez, a process towards 'a permanent cultural revolution'.

\section{Solidarity embodied}

Let us return for a moment from the ultimate goal, in reference to Gutierrez and Harvey, to the particularities of localised urban struggles. Urban social movements practice an embodied solidarity with localised urban struggles, the members of such movements mostly being the same people experiencing deep exclusion from the city. How can theological education - and theological educators - learn, practice and teach such solidarity? Would it not perhaps also require the dis-placement of theological education and educators to find themselves in peril and at risk, in struggling urban neighbourhoods? Would this not be(come) the only possible fertile soil for theologies and pedagogical praxes to practice deep solidarity?

Such solidarity would express itself in claiming a right to the city, especially for marginalised and vulnerable communities. Harvey (2012) says:

to claim the right to the city... is to claim some kind of sharing power over the processes of urbanization, over the ways in which our cities are made and remade, and to do so in a fundamental and radical way. (p. 16)

Such claims - and such solidarities - would interrupt what is often viewed as inevitable processes of capital, investment and distribution, or, indeed urban decay and regeneration, suggesting that the inevitable is changeable. Harvey (2012:16) speaks of urban social movements as the bodies interrupting the so-called urban inevitable, 'to reshape the city in a different social image from that given by the powers of developers'. These movements are often birthed out of deep struggle against death-dealing forces pushing poor people out of neighbourhoods where they once lived, displacing inhabitants of urban informal settlements or so-called slums, to make space for gentrification or new city developments (cf. Harvey 2012:18). Embodied solidarity, as practised by urban social movements, sets itself up against the privatisation of public spaces and the commodification of housing. These are solidarities in the direction of a human(e) city.

Theologically, at its deepest level, where the agency of the poor irrupts in history to imagine and make radical alternatives, we can consider it expressions of God becoming human: God's solidarity with the pain of humanity and the 
earth, expressed in movements of justice and cries for liberation (cf. Gutierrez 1988:107). God becoming flesh is a material God deeply concerned with the material conditions of 'nonpersons', or all those differently denied. Gutierrez (1988) captures it powerfully in the decisive moment of God's incarnation:

Since the Incarnation, humanity, every human being, history, is the living temple of God. The 'pro-fane', that which is located outside the temple, no longer exists. (p. 110)

In the humanity of God - or differently said, in God's incarnational solidarity - these false dichotomies or dualisms are permanently suspended.

Guiterrez (1988:120) says ' $t$ ]rue liberation will be the work of the oppressed themselves ... Living witnesses rather than theological speculation will point out, are already pointing out, the direction of a spirituality of liberation'. If one considers urban social movements as the movements of the urban poor, claiming, articulating and shaping their own struggles, we are to consider such movements to find clues for an authentic spirituality of liberation. Without a spirituality of the poor, says Gutierrez (1988:120), one cannot have a spirituality of liberation. And without a spirituality of liberation, theology cannot accompany the liberation of Christ in history. And without theological education fostering such liberationist spiritualities, through deep modelling of incarnational solidarity, churches will remain discarnate spiritual enclaves.

\section{Theological education and the church: Revisited through the irruptions of urban social movements}

This article reads urban social movements as irruptions of God's Spirit in urban histories. It then suggests that theological education and the church, to be aligned to the Spirit, need to attend well to discourses, practices and processes evident in such movements.

Firstly, we need to acknowledge, in a self-critical manner, the incongruence between our own languages or visions and our actions or embodiments. At the same time, we need to engage the epistemological distance between hope and hopelessness, interrogating why a greater urgency of hope is often more evident in urban social movements emerging from the grass root poor than in communities of faith. We need to interrogate our own locatedness.

Secondly then, can we envision a theological education - in terms of its curricula, pedagogies, institutional ethos and outcomes - as well as a church - in terms of its ecclesial practices and institutional culture - deeply informed by urban social movements? What will theological education and the church look like if it resembled a praxis marked by irruptions from below, friendship with the poor, a resistance of dominant city-making practices and recognition of informality as insurgency?

Horsley and Hanson (1985:xi-xv) showed the centrality of the peasant movements of Jesus' time, in resisting both Roman dominance and exploitation and the Jewish ruling elite. More than $90 \%$ of the population consisted of the peasantry. It is then significant that Jesus himself came from Nazareth, a peasant village, and in his parables largely drew 'analogies from the experiences of Galilean peasant life' (Horsley \& Hanson 1985:xii). They further indicate the similarity between some of Jesus' sayings and actions with those of these (prophetic) movements (Horsley \& Hanson 1985:257). If we consider urban social movements as movements of ordinary urban people, predominantly the urban poor, and often comprising large numbers of new migrants into the city from places of rural poverty, such movements show remarkable similarities to the peasant movements of Jesus' time.

How can theological education and the church not just recognise urban social movements, but also draw from them theologically, to be informed and transformed by them in relationships of mutuality? Jesus, the peasant leader of Nazareth, perhaps showed the way through his symbiotic relationship with the contexts from which he emerged.

Thirdly then, once we have scrutinised ourselves critically and allowed the postures of urban social movements to help shape us, learning from the Nazarene, we might be able to embody solidarity concretely, going way beyond a language of solidarity. We can then participate humbly in actions that will humanise the city - both people and places. And we will start to recognise these as small steps only, crucially important as they are, towards a much deeper struggle or revolution for urban justice - indeed, a journey towards a new society, where theological education and the church will seize being custodians of the status quo, rather becoming mediators of a new order.

\section{Acknowledgements Competing interests}

The author declares that he or she has no financial or personal relationships which may have inappropriately influenced him or her in writing this article.

\section{References}

Abahlali, 2016a, Guide for NGOs, academics, activists and churches seeking a relationship with the movement, posted 22 May 2007, viewed 06 April 2017, from http://abahlali.org/node/1391/

Abahlali, 2016b, University of Abahlali, viewed 06 April 2017, from http://abahlali. org/university-of-abahlali-basemjondolo/

Baadjies, M., 2016, 'I want to die here, not in Blikkiesdorp', Daily Voice, 30 August, viewed 18 April 2017, from http://www.dailyvoice.co.za/news/i-want-to-die-herenot-in-Blikkiesdorp/

Bayat, A., 1997, 'Un-civil society: The politics of the "informal” people', Third World Quarterly 18(1), 53-72. https://doi.org/10.1080/01436599715055

Bayat, A, 2000, 'From "Dangerous" Classes to "Quiet" Rebels', Politics of the Urban Subaltern in the Global South', International Sociology 15(3), 533-557. https:// doi.org/10.1177/026858000015003005 
De Beer, S.F., 2014, “"Between life and death": On land, silence and liberation in the capital city', HTS Teologiese Studies/Theological Studies 70(1), Art. \#2075, 1-7. capital city', HTS Teologiese Studies/Th
https://doi.org/10.4102/hts.v70i1.2075

De Villiers, J., 2017, 'Reasons for Tafelberg school property sale "illegitimate"- Human settlements', News24, 30 March, viewed 15 June 2017, from http://m.news24. com/news24/SouthAfrica/News/reasons-for-tafelberg-school-property-saleillegitimate-human-settlements-20170330

Douglas, M, 2002, 'From global intercity competition to cooperation for livable cities and economic resilience in Pacific Asia', Environment and Urbanization 14(1), 53-68.

Evans, J., 2017, 'Bromwell Street judge stuns with court comments', News24, 31 January, viewed 15 June 2017, from http://www.news24.com/SouthAfrica/News/ bromwell-street-judge-stuns-with-court-comments-20170131

Fanon, F., 1968, The wretched of the earth, transl. C. Farrington, Grove Press, New York.

Furlong, A., 2017, 'City of Cape Town takes bold step in Tafelberg battle', GroundUp, 28 March, viewed 15 June 2017, from http://www.groundup.org.za/article/citycape-town-bold-step/

Gerardy, J., 2010, 'It's like a concentration camp', Mail and Guardian, June, viewed 06 July 2017, from http://mg.co.za/article/2010-06-07/its-like-a-concentrationcamp

Gibson, N.C., 2011, Fanonian practices in South Africa, Palgrave Macmillan, London.

Gutierrez, G., 1988, A theology of liberation: History, politics and salvation, Orbis Books, Maryknoll, NY.

Hankela, E., 2014, Ubuntu, migration and ministry: Being human in a Johannesburg church, Brill, Leiden.

Harvey, D., 2012, Rebel cities: From the right to the city to the urban revolution, Verso, London.

Hogg, C., 2017, 'Cape Town promises social housing in Woodstock', GroundUp 31 January, viewed 08 June 2017, from http://www.news24.com/SouthAfrica/ News/cape-town-promises-social-housing-in-woodstock-20170131

Holston, J., 2009, 'Dangerous spaces of citizenship: Gang talk, rights talk, and rule of law in Brazil', Planning Theory 8(1), 12-21. https://doi.org/10.1177/1473095208 099296

Holston, J. \& Caldeira, T., 2008, 'Urban peripheries and the invention of citizenship', Harvard Design Magazine 28, 18-23.

Horsley, R.A. \& Hanson, J.S., 1985, Bandits, prophets and messiahs: Popular movements in the time of Jesus, Winston Press, Minneapolis, MN.

Huchzermeyer, M., 2011, Cities with 'slums'. From informal settlement eradication to a right to the city in Africa, UCT Press, Claremont, CA.
Kritzinger, J.N.J., 2008, Liberating whiteness: Engaging with the anti-racist dialectics of Steve Biko, viewed 08 February 2017, from http://uir.unisa.ac.za/bitstream/ Steve Biko, viewed 08 February
handle/10500/4326/Kritzinger.pdf

Merrifield, A, 2002, Dialectical Urbanism. Social Struggles in the Capitalist City, Monthly Review Press, New York.

Miraftab, F., 2009, 'Insurgent planning: Situating radical planning in the global south', Planning Theory 8(1), 32-50. https://doi.org/10.1177/1473095208099297

Moltmann, J., 1983, The power of the powerless, SCM, London.

Mortlock, M., 2017a, 'Bromwell Street residents take on judge in eviction case', Eyewitness News (EWN), 06 April, Eyew, viewed 08 June 2017, from http://ewn. co.za/2017/04/06/bromwell-street-residents-take-on-judge-in-eviction-case

Mortlock, M., 2017b, 'WC government to proceed with sale of Tafelberg property', Eyewitness News (EWN), 22 March, viewed 08 March 2017, from http://ewn.co. za/2017/03/22/wc-govt-to-proceed-with-sale-of-tafelberg-property

Murray, M., 2008, Taming the disorderly city: The spatial landscape of Johannesburg after Apartheid, Cornell University Press, New York.

Ndifuna Ukwazi, 2017, Reclaim the city, viewed 06 March 2017, from http://nu.org.za

Perkinson, J.W., 2004, White theology: Outing supremacy in modernity, Palgrave Macmillan, New York.

Pillay, S. \& Sendin, J., 2017, 'Seven reasons why reclaim the city is occupying Helen Bowden and Woodstock Hos', GroundUp, 4 April, viewed 08 June 2017, from http://www.groundup.org.za/article/seven-reasons-why-reclaim-city-occupyinghelen-bowden-and-woodstock-hospital/

Pithouse, R., 2006, Our struggle is thought, on the ground, running, Centre for Civil Society, The University of Abahlali base Mjondolo, Research Report, No.40, pp.5-47, (Research Reports 2006: Volume 1), UKZN, Durban.

Social Justice Coalition, n.d., The SJC fights for dignity, equality, and justice, viewed 18 March 2017, from http://www.sjc.org.za/

TeleSUR Reports, 2014,'Leonardo Boff - The rebel theologian', posted 26 September 2014, viewed 16 March 2017, from https://www.youtube.com/watch?v= JyxJaAlw8jU

Van Wyngaard, G.J., 2015, 'Whiteness and public theology: An exploration of listening', Missionalia 43(3), 478-492. https://doi.org/10.7832/43-3-132

Van Wyngaard, G.J., 2016, 'White theology in dialogue with black theology: Explorin the contribution of Klippies Kritzinger', HTS Teologiese Studies/Theological Studies 72(1), 1-9. https://doi.org/10.4102/hts.v72i.1.3033

Zikode, S., 2017, The restoration of our human dignity is not negotiable, talk given by S'bu Zikode at the Mzala Nxumalo Centre conference on "The Future of the Left South Africa in a Global Context", June 10, viewed 18 July 2017, from http:// abahlali.org/node/16050/ 